\title{
OCCURRENCE AND RISK FACTORS OF DIGITAL DERMATITIS IN EGYPTIAN DAIRIES
}

\author{
El-SayedA.El-Shafaey1,3, Mohamed Z. Sayed-Ahmed ${ }^{2,4}$, Sherif M. Shoeib5 \\ Sabry A. El-khodery ${ }^{2 *}$,
}

${ }^{1}$ Department of Surgery, Anesthesiology and Radiology, Faculty of Veterinary Medicine, Mansoura University, Mansoura 35516, Egypt, ${ }^{2}$ Department of Internal Medicine and Infectious Diseases, Faculty of Veterinary Medicine, Mansoura University, Mansour 35516, Egypt, ${ }^{3}$ Department of Veterinary Medicine, College of Agriculture and Veterinary Medicine, Qassim University, Buraydah 51452, Qassim, Saudi Arabia, ${ }^{4}$ Department of Clinical Pharmacy, College of Pharmacy, Jazan University, Jizan45142, Saudi Arabia, ${ }^{5}$ Veterinary Teaching Hospital, Faculty of Veterinary Medicine, Mansoura University, Mansoura 35516,Egypt

*Corresponding author, E-mail: khodery@mans.edu.eg

\begin{abstract}
In the present study, the prevalence of digital dermatitis (DD) and the related risk factors in dairy cows was investigated. For 12 months, information about the establishment of DD lesions and other claw disorders in dairy cows was collected. A questionnaire was designed to get data about age, milk yield, season, parity, transition period, concurrent diseases and biosecurity. The hind claws were more affected than fore claws (95.24 vs $4.76 \%$ ) particularly the left hind claws (56.67\%). However, The DD more prevalent during the second lactation than the third lactation (42.85 vs $36.50 \%)$ and first lactation (42.85 vs. $19.06 \%)$ which gradually decreased reaching the lowest incidence in heifer cows (42.85 vs $1.59 \%$ ). Furthermore, DD was more prevalent during summer and autumn. Based on cow level, the final step of logistic regression analysis revealed a significant relationship between DD and cow' age ( $P<0.05$; Odds Ratio [OR]: 1.01; 95\% confidence interval [Cl]: 0.67-1.47), parity (P<0.05; OR: 1.01.11; 95\% Cl: 0.47-401.93), season $(\mathrm{P}<.05$; OR: 1.36; 95\% Cl: 1.01-1.81), and transition period $(\mathrm{P}<.05$; OR: 1.53; $95 \% \mathrm{Cl}: 0.48-4.83)$. The recognition of factors which influence occurrence of DD may permit changes in herd management or breeding policies which can be applied to diminish the prevalence of DD, and can establish the appropriate preventive procedures.
\end{abstract}

Key words: digital dermatitis; dairy cows; risk factors; epidemiology

\section{Introduction}

Digital dermatitis (DD) is a global emerging digital skin disease of dairy cows, causes lameness with subsequent economic losses (1-3). Digital dermatitis decreases reproductive performance, milk production, as well as produc- tive lifespan and animal welfare $(4,5)$. The lesions of DD are mainly oval or circular, with strawberry-like appearance, with presence of a circumscribed erosive purulent epidermitis, which can develop to an ulcerative granulomatous lesion. The predilection site of typical lesions of DD are the posterior part of digits, , and 
the mid-way between the heel bulbs, and adjacent to the coronet $(6,7)$. The precise cause and factors which predispose to DD occurrence in herds are still unclear, but it seems a multifactorial disease (8).

Environmental, farm-management and individual animal factors are the suggested risks for this disease $(9,10)$. These risk factors can be split into two groups; cow-level factors (breed, parity, stage of lactation, calving season, transition period and other claw affections) (11-13). The transition period in dairy cows is the time extending from three weeks pre-calving, to three weeks post-calving. Minor alteration in the management system of dairy cows induces a dramatic effect on feed intake, health condition, locomotion and final profitability (14). Prompt alteration in both metabolic and hormonal systems occur during this period induces a stress in the cow, which is a critical determinant of the high risk of diseases in a dairy herd. Lameness may be triggered during the transition period. Physiological and behavioral changes during transition can damage the corium. This damage is not immediately apparent but results in poor hoof growth inducing DD, sole ulcers and hemorrhage (15). The pathogenesis and clinical findings of DD lesions have been well presented. However, there are no standard features of classifying the lesions, while trials have been made to characterize the lesions based on the stage and severity (16-18).

Scoring system has been presented to reflect the stages of DD $(6,19)$. Scores 1 and 2 are the initial stage of lesions, which has intact epidermis. But the score 3 is characterized by presence of ulcerative lesion. Scores 4 and 5 are the late lesions in the course of healing (19). In a study, it has been suggested that, animals could be classified based on their DD to no lesions, single lesions or recurring lesions $(20,21)$.

Reducing the occurrence of via early diagnosis and treatment is an crucial management system $(22,23)$. There are a lot of treatment options for DD; systemic antibiotics, individual topical treatment, and mass topical therapy using a footbath (24). Topical treatment of DD worldwide includes antibiotic and non-antibiotic preparations (sprays or pastes) applied with/without bandage $(25,26,27)$. Furthermore, when treatment of DD is in progress, thorough claw trimming should be done (28). In this study and epidemiological investigation on the occurrence and factors associated with digital Dermatitis in Egyptian dairies.

\section{Materials and methods}

\section{Area}

The area of study is present in the northeastern part of Egypt, at the Damietta, along with branch, of the River Nile, fifteen kilometers from the Mediterranean Sea. The study region is 200 kilometers north to Cairo. It represents approximately $5 \%$ of the total area of Delta, but $1 \%$ of the total area of Egypt.

\section{Study animals}

For 12 months, an epidemiological investigation was achieved in one dairy herd in Damietta governorate. We constructed a questionnaire to include age, milk yield, season, parity, transition period, concurrent diseases and biosecurity was provided by veterinary medical officer. A total of 63 (14\%) of 450 dairy cows were randomly selected and examined weekly for DD lesions using risk factors scores for subjective assessment of risk parameters (Table 1).

\section{Management system}

The animals were housed in a cubicle (freestall/feedlot) barn with straw-bedded stalls, and a slatted floor which was automatically scraped. The cows were tied in a long-stall barn with a daily replaced chopped straw was used as bedding on the top of rubber mats. The feeding system was a total mixed ration (TMR) for all cows, and milking was twice/day. The intake of concentrates was increased 4 weeks before calving and peaked 3 weeks after. The annual milk production per cow in the farm averaged $8500 \mathrm{~kg}$ energy-corrected milk during the year. A professional hoof trimmer trimmed the cows, feet routinely twice a year, in autumn and spring using a transportable hydraulic trimming chute. Footbaths were not used on this dairy farm during the study. Based on the approval of the Committee of Animal Welfare and Ethics, 
Mansoura University, this study was carried out.

\section{Case identification}

The clinical signs of DD in the 63 HolsteinFriesian dairy cows were recorded weekly and over 4 week after treatment. At each examination, cows were placed in a hoof trimming chute, the feet were washed manually with a water hose and a brush, and a detailed examination of the feet of each cow was performed for observation of DD lesions. Visual inspection and digital palpation were applied to evaluate the lesions of DD according to Döpfer et al. and Laven et al. (29,30). On the basis of clinical presentation, location, shape, depth, color, the diameter of the lesions and lesion maturity score (stage) were noted. The lesion diameter was measured at the widest part of the lesion in the examination stanchion using measuring tape.

\section{Statistical analyses}

For analysis of data, a commercial software program was used (SPSS version 21.0, SPSS Inc, USA). As an initial step, the descriptive statistics were presented and the distribution of risk factors among cows with DD was identified. The Association between the incidence of DD and the related factors was assessed by logistic regression on cow level. Two levels of statistics were performed, the univariate then multivariate. In univariate step, the status of cows with DD was the dependent, but the risk factor was the independent. When the significance level was at $(\mathrm{P}<.1)$, further backward stepwise multiple logistic regression was conducted. The standard parameters of logistic regression were presented finally. The association between DD and variables of clinical symptoms was assessed by chi-square test. In all steps, at $\mathrm{P}<.05$, the outcome was recorded as significant.

\section{Results}

\section{Prevalence}

Sixty-three (33.2\%) Egyptian dairy cows were proved to be infected with DD. The hind claws were significantly higher than fore claws
(95.24 vs. $4.76 \%$ ) particularly the left hind claws $(56.67 \%)$. DD was significantly higher in young age $3-5$ years than older cows ( $\geq 5$ years old) $(33 ; 52.4$ vs. $10 ; 15.9 \%)(\mathrm{P}<.05$; OR: 1.01; 95\% CI: .67-1.47). It was significantly higher during the second lactation than third lactation (27; 42.85 vs. $23 ; 36.50 \%)(\mathrm{P}<.05$; OR: 8.01; 95\% CI: 6.5-6.5) and first lactation (12; $19.06 \%$ ), which gradually decreased reaching the lowest incidence in heifer cows $(1 ; 1.59 \%)$ as showed in Fig.1A.There was a decrease in milk production in cows with DD than control cows. DD prevalence was affected by the transition period of the affected cows. It was progressively increased from calving till 3 weeks after calving. However, cows at time 0 of calving showed a significant $(\mathrm{P}<0.04)$ retraction of the lesion score. On the other hand, after calving, a significant increase $(\mathrm{P}<0.05)$, particularly during the first 3 month after calving was recorded. The seasonal prevalence of DD was summer (26, 41.27\%); autumn (21;33.34\%); winter $(9 ; 14.29 \%)$; spring $(7 ; 11.12 \%)$ as showed in Fig.1B.

\section{Univariate statistics}

The results of univariate analysis were presented in Tables 2, with the distribution of suggested risk factors associated with DD on cow levels.

\section{Multivariable analysis}

The results of this final step indicated that Hosmer and Lemeshow's goodness of fit model adequately fits the data on cow level $(\chi 2,7.89$; $\mathrm{P}=0.20)$. On cow level, age, parity, season and transition period were the potential risk factors (Table 3).

\section{Clinical findings}

A total of 63 of 190 Holstein-Frisian dairy cows were diagnosed. Sixty lesions were present on the hind claws and three on the fore claws, especially on the plantar skin over the bulb of the heels $(45 ; 71.43 \%)$, and occasionally on the anterior aspect of the interdigital cleft $(10 ; 15.87 \%)$ or adjacent to the dorsal coronet $(8 ; 12.70 \%)$. Thirty-four lesions were recorded on left hind claws, 26 on the right hind claws, 2 left fore claws and1right fore claw 
cows. while, the DD lesions were located in a cow on both hind claws. In 63 examined claws, the skin lesion appeared as strawberry (33; $52.38 \%)$, oval $(18 ; 28.57 \%)$ and circular spots $(12 ; 19.05 \%)$ on the plantar aspect of the feet (Fig.2D). Most of them were distal, but adjacent to the bulbar skin-horn junction. Small lesions $(<1 \mathrm{~cm})$ were $(16 ; 25.39 \%)$ and lesions that were assumed to be early cases were located at the skin-horn junction (commonly in direct proximity to the interdigital cleft/plantar commissure). While, the medium lesions $(1-2 \mathrm{~cm})$ were $(21,33.33 \%)$ and larger lesions $(>2 \mathrm{~cm})$ were $(26 ; 41.27 \%)$ were situated anywhere along the junction and sometimes merged to cover the entire bulbs. Lesions located exclusively on the skin of the interdigital cleft were elongated with a layered appearance. The pili in the area bordering the skin-horn junction were erected, elongated approximately 3 to 4 times their normal length, and matted. There were 5 M1 lesions (7.94\%), 54 M2 lesions (85.71\%), 3 M3 lesions 4.76\%), and1M4lesions(1.59\%)asshowedinFig.2A.TheM2lesionswerelocated over the bulb of the heel while, M1 lesions were found within the interdigital space. The M2 lesions were circumscribed areas of ulcerative, erosive dermatitis which often painful, and easily bleed when they were manipulated than other stages. The surrounding skin was reddened and the follicles appeared to be hypertrophied. Severely affected feet had a massive soft-tissue swelling in the bulbar area. There was as strongest association between M1 and M2 DD lesion. The M1 lesion has the liability to be M2 than negative one (M0). While, M2 lesions usually becomes M3-M4 in their way for recovery. There was a close link between the stage and color of lesion. Therefore, that $40(63.49 \%)$ cows showed pink/red (erosive) lesions were observed during the clinical examination. While, 10(15.87\%) cows showed brown/gray lesion and creamy/yellow (granulomatous) lesions were identified in 13 (20.63\%) cows asshowedinFig.2C.The lesion depth was varied between shallow to deep lesions. Most of the evaluated feet showed proliferative lesion $37(58.73 \%)$ cows and deep lesion in9 $(14.29 \%)$ cows. However, $15(23.81 \%)$ cows showed shallow lesions (Fig.2B).

Table 1: The risk factors scores for subjective assessment of risk parameters in 63 Holstein-Frisian Dairy cows with digital dermatitis

\begin{tabular}{lll}
\hline Risk factors scores & \multicolumn{1}{c}{ Score and Description } \\
\hline Age $($ Year $)$ & $0=1-3$ & $1=>3-5$ \\
Milk yield $(\mathrm{kg} / \mathrm{Y})$ & $2=>5-7$ & $1=4200$ \\
& $0=2100-4000$ & $3=6000-8500$ \\
2 & $=6300$ & $1=$ Spring \\
Season & $0=$ Winter & $3=$ Autumn \\
& $2=$ Summer & $1=1^{\text {st }}$ \\
Lactation number/parity & $0=$ Heifer & $3=3^{\text {rd }}$ \\
& $2=2^{\text {nd }}$ & \\
Transition period/wk & $4=4^{\text {th }}$ and over & $1=$ After calving \\
Concurrent disease & $0=$ Before calving & $1=$ Positive (mastitis, metritis, claw \\
& $0=$ Negative & affections) \\
Affected limb & $0=$ Right fore claw \\
& $2=$ Left fore claw & $3=$ Left hind claw \\
& $4=$ Both fore claw & $5=$ Both hind claws \\
\hline
\end{tabular}

$=$ Means equal 
Table 2: Odds ratios (OR; including 95\% confidence interval), frequencies, and digital dermatitis (DD) prevalence for the variables associated with DD among 63 cows in Egypt

\begin{tabular}{|c|c|c|c|c|c|c|}
\hline Category & Description & Frequency & Prevalence & OR & CI & P Value \\
\hline \multirow[t]{3}{*}{ Age } & 1- 3 Years & 20 & 31.7 & & & \\
\hline & $>3-5$ Years & 33 & 52.4 & 3.86 & $.7-21.2$ & .1 \\
\hline & $>5-7$ Years & 10 & 15.9 & 2.86 & $.5-14.01$ & .1 \\
\hline \multirow[t]{3}{*}{ Milk yield } & $\begin{array}{l}2100-4000 \\
\mathrm{Kg} / \mathrm{Y}\end{array}$ & 27 & 42.9 & & & \\
\hline & $4200 \mathrm{Kg} / \mathrm{Y}$ & 25 & 39.7 & 1.08 & $0.1-0.8$ & 1. \\
\hline & $6300 \mathrm{Kg} / \mathrm{Y}$ & 11 & 17.5 & 0.56 & 0.0- 0.7 & 1. \\
\hline \multirow[t]{4}{*}{ Season } & Winter & 9 & 14.29 & & & \\
\hline & Spring & 7 & 11.12 & .035 & $.001-1.2$ & .06 \\
\hline & Summer & 26 & 41.27 & 17.7 & $17.6-17.7$ & .50 \\
\hline & Autumn & 21 & 33.34 & .44 & $.04-4.6$ & \\
\hline \multirow[t]{4}{*}{ Parity } & Heifer & 1 & 1.59 & & & \\
\hline & 1st lactation & 12 & 19.06 & 5.6 & & \\
\hline & 2nd lactation & 27 & 42.85 & 8.1 & $6.5-6.5$ & 1.0 \\
\hline & 3rd lactation & 23 & 36.50 & 6.5 & & \\
\hline \multirow[t]{2}{*}{ Concurrent Diseases } & Negative & 0 & 0 & & & \\
\hline & Positive & 63 & 100 & & & \\
\hline \multirow[t]{4}{*}{ Limb } & Left fore claw & 20 & 31.7 & & & \\
\hline & $\begin{array}{l}\text { Right fore } \\
\text { claw }\end{array}$ & 3 & 3.73 & 3.5 & & \\
\hline & $\begin{array}{l}\text { Right hind } \\
\text { claw }\end{array}$ & 33 & 56.67 & 3.5 & & \\
\hline & Left hind claw & 5 & 7.9 & & & \\
\hline
\end{tabular}

Abbreviations: CI, confidence interval at 95\%; OR, odds ratio

Table 3: Final logistic regression model the risk factors associated with digital dermatitis in Egyptian dairy cattle on cow level

\begin{tabular}{llllll}
\hline Variable & B & SE & P & OR & Cl \\
\hline Age & .006 & 0.20045 & .98 & 1.01 & $0.67-1.47$ \\
Parity & .051 & 0.36224 & .89 & 1.01 & $0.47-1.93$ \\
Season & .304 & 0.14894 & .04 & 1.36 & $1.01-1.81$ \\
Transition period & .423 & 0.58770 & .47 & 1.53 & $0.48-4.83$ \\
Constant & .271 & 0.75946 & .72 & 56.65 & ------ \\
\hline
\end{tabular}

Abbreviation: $\beta$, regression coefficient; $\mathrm{Cl}$, confident interval at $95 \%$; OR, odds ratio; $\mathrm{P}, \mathrm{P}$ value; SE, stander error 

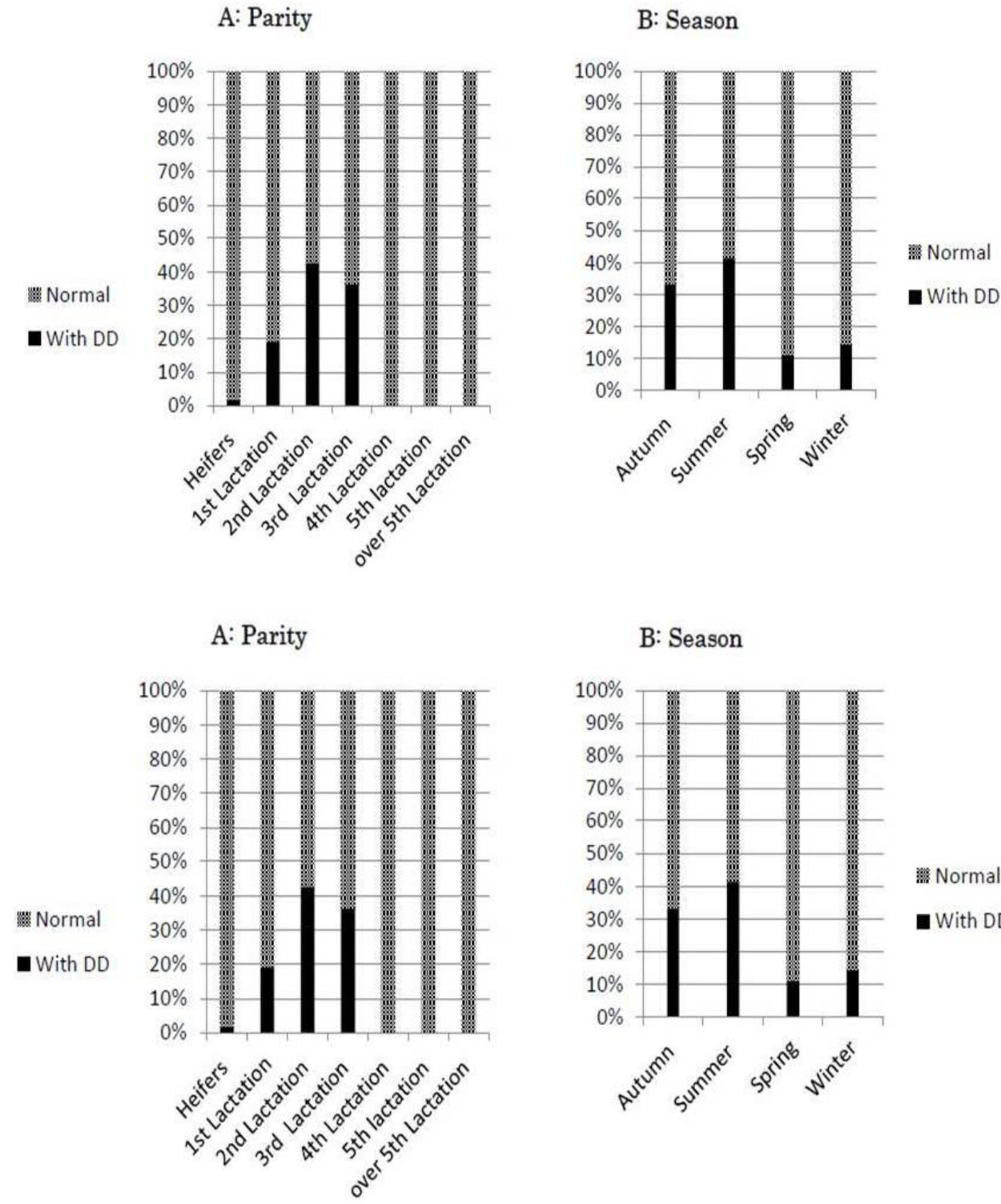

B: Season

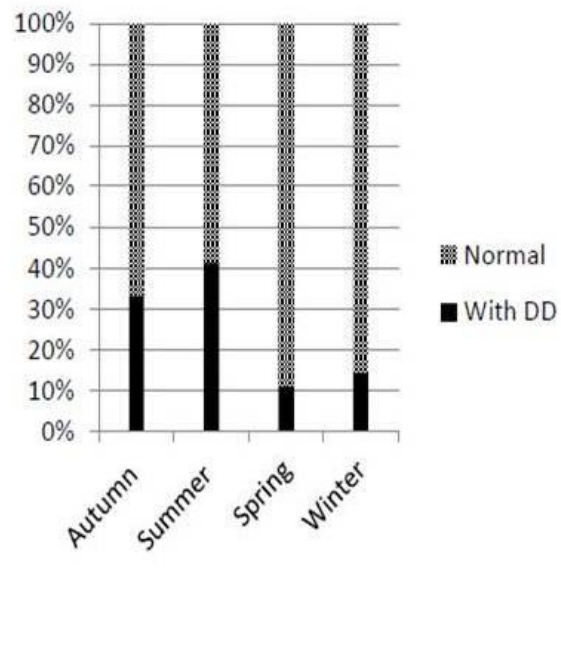

Figure 1: Effect of Parity and season on digital dermatitis in Egyptian dairies 


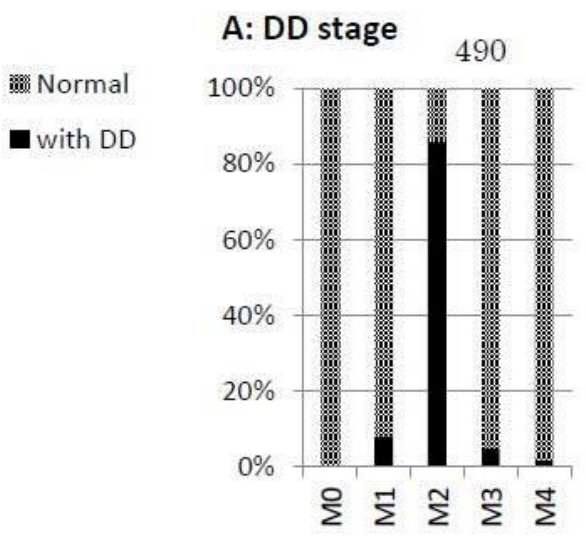

$P=0.08$ NS

D: DD shape

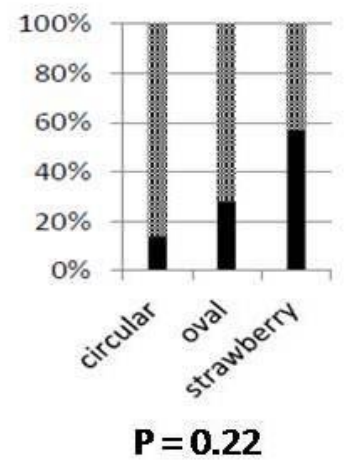

B: DD depth

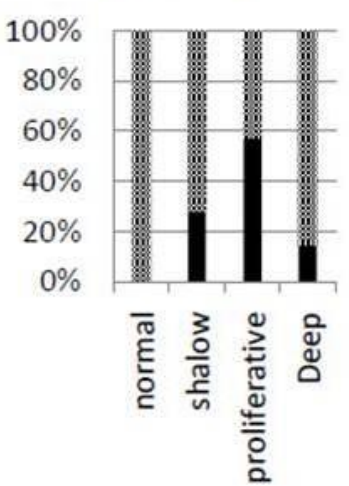

$P=0.08$ NS

E: DD size

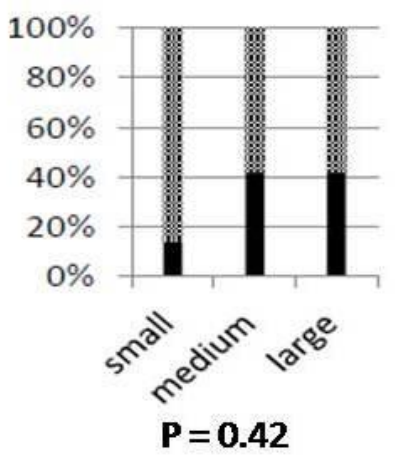

C: DD color

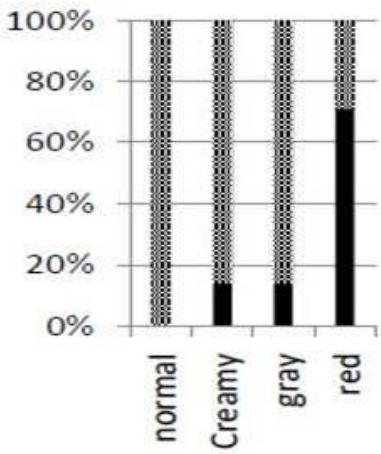

$\mathbf{P}=\mathbf{0 . 0 1}$

\section{F: DD location}

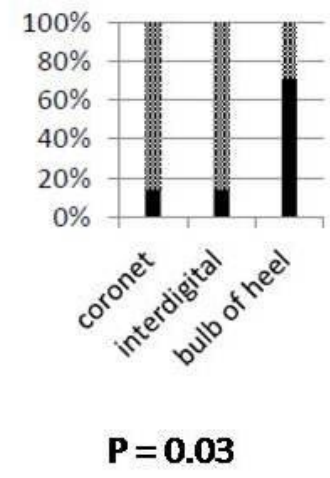

Figure 2: Effect of management system on digital dermatitis in Egyptian dairies

\section{Discussion}

Proper understanding of the predispositions factors of digital dermatitis in cattle may aid the improvement of management strategies to avoid or diminish the disease and its economic outcome (31). In our study, cow level risk factors were studied. The breed predisposition is one of the exciting causes of DD in dairy cows. Holstein cows are more susceptible to DD than other dairy breeds $(32,33)$. The present study revealed that Holstein cows were vulnerable to DD. Moreover, DD is recognized to be more common in the pelvic feet than in forefeet $(34,35)$.
In our results, the lesions of DD were observed exclusively in the hind claws more affected than fore claws (95.24 vs.4.76\%) particularly the left hind claws $(56.67 \%)$. This could be attributed to longer periods of cows recumbency on such side with their left hind leg positioned under the abdomen in a somewhat contaminated, moist, and warm site (35).

The current results provide an idea about the occurrence and the important associated factors of DD in dairy cows. The disease predominance in the current study was $32.2 \%$ in Egyptian dairy cows. Such finding is in concurrence with that of earlier studies in dairy cows $(31,36)$.In Swedish dairy cows, the rate of the disease is 
higher $(41 \%)$ than that of the current findings (27). However, in Netherlands, DD were found less prevalent $(20 \%)$ than in our study (3). Parity was significantly higher during the second lactation than 3rd lactation $(27 ; 42.85$ vs 23 ; $36.50 \%)$ and these results agree with Holzhauer et al. (3), who reported that there was a negative relationship between prevalence of DD and parity. At 30-60 days in milk and at the third parity cow, the odds ratio is higher than other times. The presence of concurrent claw affection were increased the prevalence of DD in dairy cows up to $100 \%$. This results was agree with Holzhauer et al. (3), who found that other claw diseases, as interdigital phlegm on, hyperplasia, and heel horn erosion predispose to the disease. Incidence of DD was higher in dairy cows in the second and third lactation number than in subsequent lactations or heifer. This is in agreement with results presented by $(12,3,37)$ who stated that, DD is an infectious disease and decreased incidence in older cows might be related to increased local immunity. Limited research has focused specifically on the relationships among DD prevalence and the transition period. The results of the present study showed that, throughout the transition period, the cows are more liable to develop lesions of DD than in other lactating months. At transition period, the period of high risk for DD, the cows are commonly liable to external influences, and clinical diseases (38).Abrupt environmental and metabolic changes during the transition period may explain the increased probability of hoof and horn diseases during this period.

The seasonal changes in calving-related management and environment are the main stressors, which play a significant role in the occurrence and severity of DD. The seasonal prevalence of DD in the present study was higher in summer and autumn in comparison with winter and spring. Interestingly, the housing system has been also found a main risk factor for DD $(33,35)$. The housing system of selected farm for this study was free-stall with the cows tied in a long-stall barn, so there might be an association with prolonged housing periods and the increased prevalence of DD.
There is a strong association between wet/dirty claw environments and the occurrence of DD. It has been observed that housing on concrete floor has higher odds than on a slatted floor with manure scraper (40). In this study, dairy cows were housed in a cubicle barn with mattress-bedded stalls, and a slatted floor which was automatically scraped. Frequent removal of cows manure would diminish the undesirable effects of the unhygienic and wet claw environment, via increasing the resistance of the claw capsule to erosions and subsequent bacterial infection $(40,41)$. In this study, most of the DD lesion definition such as diameter, shape, color, depth and location were evaluated as shown in table/figure. In dairy cows, M1, M2have been reported the major types of lesions. The M2 lesions are circumscribed areas of ulcerative, erosive dermatitis. Due to involvement of the dermis, the lesions are painful and affected animals are lame. Digital dermatitis lesions were assed everywhere on the solar aspect of the claws of the affected dairy cow included in this study. The heel bulbs are close together which more prone to continually being moist, which favors the development of DD especially M2 lesions (42). However, the M1 lesions were located in the interdigital space which has some aeration and dryness than the heel bulbs.

The rate of development and resolution of DD lesions were evaluated along the weekly observation of the affected claws. Moreover, the changes in the lesion from stage to another in the same claw were also assessed weekly. The shift among various stages of DD can progress within one month. Therefore, weekly observation would be beneficial in understanding the changes in DD lesions stages without missing even small lesions. The majority of transitions between different stages of DD have steady order, where the transitions between M2 and M4 are the most common, though transitions between M4 and M1 have also been recorded. These present findings coincide with those reported in previous studies $(43,44,45)$. 


\section{Conclusions}

The results of this study provide an idea about the prevalence and risk factors of digital dermatitis in dairy cows in Egypt, Because of the interrelation between infectious causes of claw diseases, an effective interference against DD should directed to an integrated approach to the control of all infectious claw diseases. Furthermore, the recognition of factors which influence occurrence of DD may permit changes in herd management or breeding policies which can be applied to diminish the prevalence of DD, and can establish the appropriate preventive procedures.

\section{Conflict ofinterests}

None of the authors of this article has a financial or personal relationship with other people or organizations that could appropriately influence or bias the content of the article. There are no funding sources for this study.

\section{References}

1. Laven RA, Proven MJ. Use of an antibiotic footbath in the treatment of bovine digital dermatitis. Vet Rec 2000; 147: 503-6.

2. Manske T, Hultgren J, Bergsten C. Topical treatment of digital dermatitis associated with severe heel-horn erosion in a Swedish dairy herd. Prev Vet Med 2002; 53: 215-31.

3. Holzhauer M, Hardenberg C, Bartels CJM, Frankena K. Herd and cow-level prevalenceofdigitaldermatitisinTheNetherlandsandassociatedriskfactors.J Dairy Sci. 2006; 89:580-8.

4. Capion N. Animale Welfare and digital dermatitis. Cattle Consultancy Days: 2008;23-6.

5. Andrew P Fidler, Mark L Alley, Geof W Smith. Evaluation of a Serpens speciesbacterin for treatment of digital dermatitis in dairy cattle. Research in Vet Sci 2012;93: 1258-60.

6. Dopfer D, Koopmans A, Meijer FA, Szakall I, Schukken, YH, Klee W, Bosma RB, Cornelissevan JL,Asten AJ, ter Huurne A A H M. Histopathologicaland bacteriological evaluation of digital dermatitis in cattle, with special reference to spirochaetes and Campylobacter faecalis. Vet Rec 1997; 140: 620-3.

7. Shearer JK, Hernandez J: Efficacy of two modified nonantibiotic formulations (Victory) for treatment of papillomatous digital dermatitis in dairy cows. J Dairy $\quad$ Sci 2000; 83: 741-5.
8. Dirksen G, Gründer H.D, Stöber M: InnereMedizin und Chirurgie des Rindes: Parey in MVS Medizinverlage: Stuttgart, Germany 2005; 5.

9. Read DH, Walker RL: Papillomatous digital dermatitis (footwarts) in California dairy cattle: clinical and gross pathologic findings. J Vet Diagnostic Invest 1998; 10: 67-6.

10. Rodriguez-Lainz A, Hird DW, Walker RL, Read DH. Papillomatous digital dermatitis in 458 dairies. J American Vet Med Ass 1996; 209: 1464 7.

11. Rodriguez-Lainz A, Melendez-Retamal P, Hird DW, Read DH, Walker RL. Farm-and hostlevel risk factors for digital dermatitis in Chilean dairy cattle. Prev Vet Med 1999; 42: 87-97.

12. Somers JGCJ, Frankena K, NoordhuizenStassen EN, Metz JHM. Risk factors for digital dermatitis in dairy cows in cubicle housing systems in The Netherlands. Prev Vet Med 2005a; 71: 11-21.

13. Holzhauer M, Hardenberg C, Bartels CJM, Frankena K: Herdand cow-level prevalence of digital dermatitis in The Netherlands and associated risk factors. J Dairy Sci 2006; 89: 580--8.

14. Emanuelson U and Oltenacu PA. Incidences and effects of diseases on the performance of Swedish dairy herds stratified by production. J Dairy Sci 1998; 81:2376--82.

15. Grant R J, and Albright JL: Feeding behavior and management factors during the transition period in dairy cattle. J AnimSci 1995; 73:2791-803.

16. Dopfer D, Willemen MA: Standardization of infectious claw diseases. In: Lischer, Ch., Ossent, P. (Eds.), Proceedings of the 10th International Symposium on Lameness in Ruminants, Lucerne, Switzerland.1998; 244--54.

17. Vink DW. Investigating the epidemiology of Bovine Digital Dermatitis: Causality, transmission and infection dynamics. Thesis, Doctorate of Philosophy, University of Liverpool, 2006.

18. Dopfer D, Anklam K, Mikheil D, Ladell P. Growth curves and morphology of three Treponema subtypes isolated from digital dermatitis in cattle. Vet J 2012; 193: $\quad$ 685-93.

19. Manske T, Hultgren J, Bergsten C: Topical treatment of digital dermatitis associated with severe heel-horn erosion in a Swedish dairy herd Prev Vet Med 2002; 53: 215-31.

20. Dopfer D, van Boven MR, de Jong, MCM: A mathematical model for the dynamics of digital dermatitis in groups of cattle to study the efficacy of group-based therapy and prevention strategies. In: Joshi, N.P., Herdt, T.H. (Eds.), Proceedings of the 12th International Conference for Production Diseases in Farm Animals. 2004; 138. 
21. Holzhauer M, Dopfer D, de Boer J, van Schaik G. Effects of different intervention strategies on the incidence of papillomatous digital dermatitis in dairy cows. Vet Rec 2008a; 162: 41-6.

22. Read DH, Walker RL: Papillomatous digital dermatitis (footwarts) in California dairy cattle. clinical and gross pathological finding. J Vet Diag Invest 1998;10:67-76

23. Dirksen G, Gründer HD, Stöber M: InnereMedizin und Chirurgie des Rindes: Parey in MVS edizinverlage: Stuttgart, Germany: 2005; 5.

24. Shearer JK, Elliot JB. Papillomatous digital dermatitis: treatment and control strategies-part 1. Compend Contin Educ Pract Vet 1998; 20:158-65.

25. Rodriguez-Lainz A, Melendez-Retamal P, Hird DW, Read DH, Walker RL. Farm and host-level risk factors for digital dermatitis in Chilean dairy cattle. Prev Vet Med 1999; 42: 87-97.

26. Moore Dale A, Steven L. B, Marla L. T, Vasyl K: Efficacy of a nonantimicrobial cream administered topically for treatment of digital dermatitis in dairy cattle. J Am Vet Med Ass 2001; 219: 1435-8.

27. Manske T, Hultgren J, Bergsten C: Prevalence and interrelationships of hoof lesions and lameness in Swedish dairy cows. Prev Vet Med 2002; 54: 247-63.

28. Kofler J, Pospichal M, Hofmann-Parisot, M Efficacy of the Non-antibiotic Paste Protexin HoofCare for Topical Treatment of Digital Dermatitis in Dairy Cows. J Vet Med A 2004; 51: 447-52.

29. Döpfer D, Koopmans A, Meijer FA, Szakall I, Schukken YH: Histological and bacteriological evaluation of digital dermatitis in cattle, with special reference to spirochaetes and campylobacter faecalis. Vet Rec1997; 140: 620-3.

30. Laven R: Control of digital dermatitis in cattle. In Practice, 2001; 23: 336-34.

31. Ettema JF, Østergaard O. Economic decision making on prevention and control of clinical lameness in Danish dairy herds. Livestock Sci 2006; 102, 92-106.

32. Rodriguez-lainz A, David WH, Carpenter TE: Case-control study of digital dermatitis in southern California dairy farms. Prev Vet Med 1996; 28: 117-31.

33. Murray RD, Downham DY, Demirkan I, Carter SD Some relationships between spirochaete infections and digital dermatitis in four UK dairy herds. Res Vet Sci 2002; 73: 223-30.

34. Murray RD, Clarkson MJ, Downham DY, Faull WB, Hughes JW, Manson FJ, Merritt JB, Russell WB, Sutherst JE, Ward WR. Epidemiology of lameness in dairy cattle: description and analysis of foot lesions. Vet Rec 1996; 138: 586-91.

35. Cramer G, Lissemore KD, Guard CL, Leslie KE, Kelton DF. Herd-and cow-level prevalence of foot lesions in Ontario dairy cattle. J. Dairy Sci 2008; 91:3888-95.

36. Somers JG, Frankena CJ, Noordhuizen-Stassen K, Metz EN. Risk factors for digital dermatitis in dairy cows in cubicle housing systems in The Netherlands. Prev Vet Med 2005a; 71: 11-21.

37. Nielsen B, Thomsen P, Sorensen J: A study of duration of digital dermatitis lesions after treatment in a Danish dairy herd. Acta Vet Scand 2009; 51: 27-31.

38. Argaez-Rodriguez F, Hird DW, de Anda JH, Read DH, Rodriguez-Lainz A: Papillomatous digital dermatitis on a commercial dairy farm in Mexicali, Mexico: incidence and effect on reproduction and milk production. PrevVet Med 1997; 32:

39. Hultgren J, Bergsten C. Effects of a rubber slatted flooring system on cleanliness and foot health in tied dairy cows .Prev Vet Med. 2001; 52: 75-89.

40. Wells SJ, Garber LP, Wagner BA. Papillomatous-digital dermatitis and associatedrisk factors in US dairy herds. Prev Vet Med 1999; 38: 11-24.

41. Somers JG, Frankena K, Noordhuizen-Stassen EN, Metz JH: Prevalence of clawdisorders in Dutch dairy cows exposed to several floor systems. J Dairy Sci 2003; 86: 2082-93.

42. Read DH, Walker RL. Papillomatous digital dermatitis (footwarts) in Californiadairy cattle: clinical and gross pathologic findings. J Diag Invest 1998; 10:67-76.

43. Berry SL, Dopfer D, Burgi K, Cook N. A longitudinal study on the transition ofdigital dermatitis lesions for 11 months after topical treatment with lincomycin H Clusing 4 scoring systems. In: Proceedings of 15th International Symposium on Lameness in Ruminants, Kuopio, Finland 2008; 913: 302-3.

44. Dopfer D, Bennett TB, Cook NB. Dynamics of digital dermatitis infection spread in a large free stall housed Wisconsin dairy herd. In: Proceeding from The 15thInternational Symposium and the 7th Conference on Lameness in Ruminants,Kuopio, Finland 2008; 9-13.

45. Holzhauer M, Bartels CJM, Dopfer D, van Schaik G. Clinical course of digital dermatitis lesions in an endemically infected herd without preventive herd trategies. Vet J 2008b; 177: 222-30. 